\title{
Opór rodzący wyobraźnię. Wprowadzenie
}

Uczestnictwo w kulturze to nie monologiczne praktyki artystyczne, polityczne, naukowe, podróżnicze czy inne, w których sprawstwo stoi po stronie artysty, polityka, naukowca, podróżnika. Uczestnictwo nie jest jedynie praktyką twórców. Nie jest też strategią jedynie odbiorców, którzy wchodząc $\mathrm{w}$ interakcję $\mathrm{z}$ dziełem, są przez nie pobudzani, angażowani. Jest to co prawda aktywizacja widza-odbiorcy, lecz w akcie uczestnictwa dochodzić musi do dialogu (znaczeń, sensów, wartości, norm itp.), do współpracy powstałej z wzajemnego porozumienia lub krytycznego oglądu, dystansu (negocjacji znaczeń, sensów wartości, norm itp.). Zakładając różny stopień autorefleksji i krytyczności, partycypacja zmierza do rozpoznania pewnego oporu, przeszkody, jaką stawia rzeczywistość. To nie gładkie, rozproszone percypowanie świata, lecz napotykanie niezgody, poważne, odpowiedzialne traktowanie tego, kto stoi po drugiej stronie dialogicznej wymiany. To zaś rodzi potrzebę bezpośredniego działania, czynnego zaangażowania, aktywizmu.

Można wobec tego powiedzieć, że gdy rzeczywistość jest przez nas kulturowo interpretowana, gdy w ogóle ją dostrzegamy, gdy przestaje być przezroczysta i oczywista, a jej fragmenty nie jawią się nam jako płynne, rozrywkowe, lekkie, satysfakcjonujące i szczęśliwe, lecz — przeciwnie - jako refleksyjne, przynoszące cierpienie, ciążące, zbyt posągowe, nie do ruszenia, wtedy pojawia się opór, chęć transformacji, przekształcenia, ustanowienia nowej sytuacji. Łatwo wtedy pomyśleć, że uczestnictwo to mocny, krytyczny, wręcz aktywistyczny, konfrontacyjny i wyraźnie teleologiczny sposób bycia w kulturze. Z drugiej jednak strony uczestnictwo rozumiane jako tworzenie sieci współpracy, dialogicznej wymiany, intersubiektywnie budowanej rzeczywistości nie musi zakładać żadnej opozycji wewnątrz-/zewnątrzsystemowej. Tu opór nie pochodzi z peryferii po to, by rozsadzić centrum, a transformacja systemu nie następuje przez wdarcie się do jego środka radykalnie wywrotowych sił.

Richard Sennett wyróżnił dwa rodzaje oporu: ten, który zastajemy w świecie gotowym, który blokuje nasze działania, i ten, który jest przez nas wytwarzany ${ }^{1}$. To opór, który sprawia, że wszystko może potoczyć się inaczej.

Opór zastany to wyzwanie, jakie rzuca nam rzeczywistość, to przeszkody, tarcia, doświadczanie trudności, które nigdy nie jest doświadczaniem izolowanym społecznie. Opór wytworzony to koncepcyjny, krytyczny moment naszego działa-

1 R. Sennett, Etyka dobrej roboty, przeł. J. Dzierzgowski, Warszawa 2010, s. 279. 
nia, moment, w którym odczuwamy „szorstki grunt rzeczywistości”2, z piętrzącą się niezgodą, wątpliwościami, niepewnością, złością, buntem, strachem, chęcią zmiany. Wtedy to my rzucamy wyzwanie rzeczywistości, uruchamiamy siły odśrodkowe w życiu społecznym, tworzymy więzi i umacniamy relacje, by jej się oprzeć.

Uczestniczymy w świecie, napotykając w nim opór (opór zastany), ale i tworząc wspólnie, razem, aktywnie alternatywne praktyki artystyczne, polityczne, naukowe, rekonfigurując przestrzeń, tworząc nowe sposoby zamieszkiwania, mówienia, przekształcania miejsc czy przyrody. Można ten ruch wykonać na wiele sposobów, według wielu możliwych schematów i w różnych sieciach: można stosować opór bierny lub aktywny, przez miejskie ruchy, realne lub wirtualne wspólnoty bądź w pojedynkę. W mieście, lecz również w innych formach kolektywnego działania, wyłania się wielość podmiotów komunikujących się i partycypujących we wspólnie wytworzonej przestrzeni. Opór nie oznacza wtedy tworzenia subiektywnych strategii czy „subiektywnych miast”, lecz przestrzeń kooperacji, praktykowania współpracy.

Przyjmując wyzwanie, które rzuca nam świat, wystawiając się na opór zastany, można go „gładko obejść”, uczestniczyć w świecie w sposób niemal niewidoczny, stosując opór dyskretny.

„Restauracja — na przykład filiżanki, ale i rytuału — pozwala odzyskać autentyczność, unieważnić zniszczenie i zużycie. Doskonalący ją fachowiec staje się sługą przeszłości" ${ }^{3}$ - pisze Sennett. Taka rekonstrukcja wymaga od podmiotu działającego skromności; jest on raczej narzędziem, celem nie jest zaznaczenie swojej obecności na obiekcie, lecz utrzymanie stanu z przeszłości. Nie oznacza to, że podmiot jest bierny, lecz jedynie dyskretny, że nie manifestuje on swego działania.

Można jednak bardziej odważnie zmierzyć się z rzeczywistością, można śmielej rzucić oporowi wyzwanie, można rzeczywistość u s p ra w n i a ć, a to oznacza, że ów akt usprawnienia wymaga od podmiotu działającego umiejętności, kunsztu, wiedzy i wynalazczości. Cel i użycie pozostają takie same, zmieniają się za to środki. Wreszcie, wbrew diagnozom Sennetta, który powiada, że we współczesnych nam społeczeństwach mamy skłonność do wyzwolenia się od oporu, można podjąć re k o nfig u ra c ję polegającą na zmianie funkcji i formy obiektu. Można odcisnąć na rzeczywistości swoje piętno, radykalnie ją przekształcić. To zaś wymaga improwizacji (która jest możliwa dlatego, że nie ma z góry narzuconych formalnych powiązań, a zatem możliwe są różne przekształcenia), ale też i planowania, zaangażowania, doświadczenia. Radykalne eksperymenty społeczne opie-

2 To określenie L. Wittgensteina przywołuje Agata Skórzyńska w swojej pracy Czy możliwe jest kulturoznawstwo aktywistyczne? Partycypacja w perspektywie filozofii praxis, zamieszczonej w tym numerze.

${ }^{3}$ R. Sennett, Razem. Rytuaty, zalety i zasady wspótpracy, przeł. J. Dzierzgowski, Warszawa 2013, s. 284. 
rają się bowiem na tworzeniu nowych form współpracy, które nie są narzędziem politycznych taktyk, lecz celem.

Rekonstrukcja to forma uczestnictwa, która najmniej wymaga zmiany, ale i widzialności podmiotu:

Usprawnienie jest nieco bardziej zorientowane na teraźniejszość i bardziej strategiczne. [...] [W] przypadku usprawnienia społecznego udaje się z kolei lepiej realizować stare cele za pomocą nowych programów i polityk. Rekonfiguracja ma bardziej eksperymentalny charakter i potrzebuje mniej formalnych procedur. Zabawa starą maszyną prowadzi do przekształcenia jej przeznaczenia i funkcji. Zrekonfigurowane relacje społeczne mogą zaś stać się bardziej otwarte szczególnie ,jeśli w grę wchodzić będzie nieformalność. Z tych trzech rekonfiguracja jest najbardziej angażująca"4.

Oto właśnie praktyki ujęte przez Sennetta w metaforę pracy-naprawy, aktywności podmiotu sprawczego w świecie. Jego propozycja jest cenna dlatego, że kładzie akcent na materialność, relacyjność działań i obiektów, ale ich nie rozszerza w nieskończoność. Ograniczeniem takim jest bowiem ludzka praca, ludzka aktywność. Nie chcę przez to powiedzieć, że Sennett wyłącza ze swojej propozycji podmioty-nie-ludzkie. One też działają, na przykład przedmiot stawiający opór w rzemieślniczej pracy prowokuje do zmiany, reorganizacji jej rytmu, gestów, przemyślenia i przekształcenia nawyków, a nawet zmiany rytuału, kreatywnej współpracy z oporem i stosowania „siły minimalnej”. Być może propozycję Sennetta można traktować jako inspirację do bardziej zaawansowanego i już mniej metaforycznego konceptualizowania kategorii „uczestnictwa w kulturze”?

Autorzy zaprezentowanych w tym numerze „Prac Kulturoznawczych” artykułów pokazują czytelnikowi różne rodzaje praktyk: od naprawiania po usprawnianie i rekonfigurację społecznej rzeczywistości. Łączy je, w różnym stopniu eksponowana, perspektywa performatywna. U każdego z autorów na pierwszym planie teoretycznych refleksji pojawia się bowiem podmiot sprawczy oraz jego skłonności do myślenia krytycznego i kwestionowania rzeczywistości.

Dziś podmioty te widoczne są zwłaszcza w postaci ruchów oporu (jednak nie zawsze rozumianych na sposób Castellsa ${ }^{5}$ ), obywatelskich ruchów miejskich czy różnego rodzaju wspólnot. Często wytwarzają one polityczny potencjał mniej lub bardziej radykalnych rekonfiguracji przez partyzantkę, kłusownictwo, nieuprawnione użycie, rozbijając w ten sposób systemowe techniki władzy ${ }^{6}$.

Znów, podążając za Sennettem, powiedzieć można, że obranym przez nich modusem działania jest przede wszystkim bycie razem, oparte na pewnych rytuałach współpracy, choć nie brak i takich działań, w których praktyki kooperacyjne zawodzą, rodząc często przykre konsekwencje. By móc jednak stawiać opór rze-

4 Ibidem, s. 284-285.

5 Nie chodzi bowiem o tożsamości oporu zdefiniowane przez M. Castellsa w Sile tożsamości, formowane jako wspólnoty wykluczonych.

${ }^{6}$ Zob. M. de Certeau, Wynaleźć codzienność. Sztuki działania, przeł. K. Thiel-Jańczuk, Kraków 2008, s. 35-37. 
czywistości, aktywnie uczestniczyć, usprawniać czy rekonfigurować, potrzeba nie tylko współpracy z innymi oraz z tym, co nie-ludzkie, wyczucia „materiału”, lecz potrzeba także kolektywnego przekazywania wiedzy, doświadczeń i umiejętności, potrzeba wreszcie „koordynacji ręki i głowy”, działań i refleksji, praktyki i teorii.

Aktywistyczne rozumienie uczestnictwa, obecne w wielu tradycjach myślenia o kulturze często posługuje się kategorią praxis, dzięki której doskonale widać właśnie ową koordynację ręki i głowy. Choć współczesne społeczeństwa są „W stanie oblężenia"7, to jednak budowanie wspólnej przestrzeni nadal przybiera różne formy ruchów społecznych czy wspólnot, zawsze jednak wymagają one kooperacji. Poddanie ich refleksji i krytycznemu oglądowi zdrowego rozsądku jest niezbędne, jeśli nie chcemy dopuścić do przekształcenia rytuałów społecznych w spektakl. W nich ludzie wkraczają bowiem w ponadjednostkową sferę intersubiektywnie podzielanej ekspresji. Gdy nie podejmują tego angażującego gestu i nie uczestniczą w społecznych rytuałach, to jedynie przeżywają spektakl, w którym wyraźnie widać podział na biernych widzów i aktywnych wykonawców. Obserwatorzy nie uczestniczą, lecz percypują, nie współpracują i nie tworzą, lecz podziwiają. „Partycypacja wymaga ustalenia milczących reguł, konwencji i rytuałów wymiany [...], lecz jednocześnie konieczne jest pozostawienie ludziom swobody interakcji" ${ }^{8}$. Rytuał daje jednostkom siłę, odzyskuje bowiem powierzchowny, codzienny wymiar ich doświadczeń. Lecz do tego potrzeba angażującego gestu dialogicznej wymiany. W tym sensie współczesne ruchy przypominają nowoczesne laboratoria, w których odkrycia techniczne przekształcają relacje między mistrzem a pracownikami. Laboratorium potrzebuje praktyk konwersacji, nieformalnej komunikacji, której rezultatem jest otwarta dyskusja na temat hipotez, procedur i rezultatów. To zaś sprawia, że skupiamy się na sytuacji społecznej, w której uczestniczymy, a nie na samym sobie. Dlatego właśnie aktywne uczestnictwo, a nie bierne oglądanie (podziwianie spektaklu) ,afirmuje zaufanie pokładane przez człowieka we własnych doświadczeniach. Dla kreatywności ogromnie ważne jest, by osoba lokowała się poza obiektem swego rozumienia"9. Dlatego właśnie eksponowana jest rola krytycznego, koncepcyjnego oglądu rzeczywistości, właśnie ów moment wytworzonego oporu, który od diagnozy i wspólnego budowania społecznej definicji sytuacji, kooperacji i wymiany, wiedzie do terapii i zmiany.

Humanistyka zatem musi działać! Jest swego rodzaju ,instrukcją ekspresywną" 10 , w równym stopniu zaangażowaną i angażującą. Stosuje różne metodologie: utożsamiając się z podmiotami badanymi lub z samym ,problemem”, budując

7 Zob. Z. Bauman, Społeczeństwo w stanie oblężenia, przeł. J. Margański, Warszawa 2006.

8 R. Sennet, Razem, s. 77.

9 Ibidem, s. 155. Sennett cytuje w tym miejscu M. Bachtina, Speech Genres and Other Late Essays, Austin 1986, s. 7.

10 R. Sennett, Etyka dobrej roboty, s. 224. 
narracje pozwalające wyrwać czytelnika z oswojonego miejsca, by wprowadzić go w inny, obcy społeczny rytuał. Język uczula na trudne momenty społeczne, które humanistyczna narracja antycypuje, często wykorzystując metafory. W ten sposób humanistyka w działaniu unika problemu „martwej denotacji”, stając się właśnie instrukcją ekspresywną, częścią praxis, doprowadzając do sprawnej koordynacji głowy i ręki. „Ekspresywne wskazówki stanowią spoiwo między technicznym fachem a wyobraźnią. Można stosować je więc do uczenia kogoś gry na instrumencie, filozofii, obsługi komputera" "11. Pół wieku temu Zygmunt Bauman określił tego typu humanistykę jako ,inżynierię przez racjonalizację"12. Owa inżynieryjna metaforyka oddać wtedy miała praktyczny wymiar wiedzy humanistycznej.

Dlatego czytelnikowi pragniemy w Archiwum „Prac Kulturoznawczych” przypomnieć tekst Zygmunta Baumana Antonio Gramsci, czyli socjologia w dziataniu $^{13}$. Niezwykle celnie wpisuje się bowiem on w problematykę uczestnictwa w kulturze w jego aktywistycznym, performatywnym wymiarze.

Magdalena Matysek-Imielińska

\footnotetext{
11 Ibidem, s. 240.

12 Z. Bauman, Wizje ludzkiego świata, Warszawa 1964.

13 Ibidem. Socjologia włoskiego filozofa jest dla Baumana przykładem takiej właśnie „inżynierii przez racjonalizację".
} 